\title{
PALEOBIOLOGY AND PALEOBIOGEOGRAPHY OF SCLERORHYNCHID SAWFISHES (CHONDRICHTHYES, BATOMORPHII)
}

\author{
Jürgen KRIWET'and Karina KUSSIUS ${ }^{2}$ \\ ' Institut für Paläontologie. Museum für Naturkunde, Humboldt-Universität \\ Berlin, Invalidenstraße 43. D-10115 Berlin (Germany). \\ 2Institut für Paläontologie, Freie Universität Berlin, Malteserstraße 74-100). \\ 12249 Berlin (Germany).
}

\begin{abstract}
Kriwet, J. and Kussius, K. 2001. Paleobiology and paleobiogeography of sclerorhynchid sawfishes (Chondrichthyes, Batomorphii). [Paleobiología y paleobiogeografía de los peces sierra esclerorrínquidos (Chondrichthyes, Batomorphii).] Revista Española de Paleontología, no extraordinario, 35-46. ISSN 02136937.
\end{abstract}

\begin{abstract}
Sclerorhynchid sawfishes are a monophyletic group of Cretaceous selachians. They resemble modern sawfishes in the outer morphology and by having a hypertrophic rostral cartilage armed with lateral rows of spines. Generally, sclerorhynchid sawfishes were inhabitants of warm, shallow tropical and subtropical marine environments. Teeth of the oldest sclerorhynchid sawfishes from Spain are presented. They belong to Onchopristis Stromer and come from the lower Barremian of eastern Spain. The paleobiology and paleogeographic pattern of sclerorhynchid sawfishes is reviewed and discussed.
\end{abstract}

Keywords: Sclerorhynchidae, Batomorphii, paleobiology, paleobiogeography.

\section{RESUMEN}

Los peces sierra esclerorrínquidos forman un grupo monofilético de seláceos cretácicos. Se asemejan a las formas actuales de peces sierra en la morfología externa y en la presencia de un cartílago rostral hipertrófico armado con filas laterales de espinas. La paleta rostral fue usada de la misma manera que los prístidos actuales. Generalemente los esclerorrínquidos habitaron medios tropicales y subtropicales de aguas someras y cálidas. Se presentan en este trabajo los dientes de Onchopristis Stromer, el más antiguo esclerorrínquido de España. Así mismo se discute la paleobiología y patrones de distribución de los peces sierra esclerorrínquidos.

Palabras clave: Sclerorhynchidae, Batomorphii, paleobiología, paleobiogeografía.

\section{INTRODUCTION}

Sclerorhynchid sawfishes are a monophyletic group of extinct batoid fishes. They resemble modern sawfishes of the family Pristidae by having a long and slender body with ventral gill slites, pectorals attached to the head and a hypertrophic rostrum forming a rostral blade which is armed with lateral rows of rostral spines (Fig. 1). Generally, sclerorhynchids are placed within Rajiformes on subordinal rang (Sclerorhynchoidei Cappetta, 1980). So far, Sclerorhynchoidei comprises a single family, Sclerorhynchidae, which was errected by Cappetta (1974). The oldest sclerorhynchid remains (isolated oral teeth) are from the Early Cretaceous of Europe, North Africa and North America (e.g., lower Barremian of
Spain, Kriwet (1999), Albian of northern Africa, Haug (1905), Stromer (1927); Aptian-Albian boundary of Texas, Thurmond (1971), Branch and Mosley (1997). At least 16 genera with at least 40 species have been described up to now which are only restricted to the Cretaceous period. The most common Early Cretaceous sclerorhynchid sawfish is Onchopristis Stromer, 1917. Although most sclerorhynchids are known by isolated rostral or oral teeth only, Upper Cretaceous sediments of Egypt yielded well preserved rostral blades. Furthermore, articulated skeletons of several genera are known from the Cenomanian and Santonian of Lebanon (Cappetta, 1980).

Similar neoselachian sharks evolved convergently. The sawsharks (Pristiophorifomes) first appeared in the 


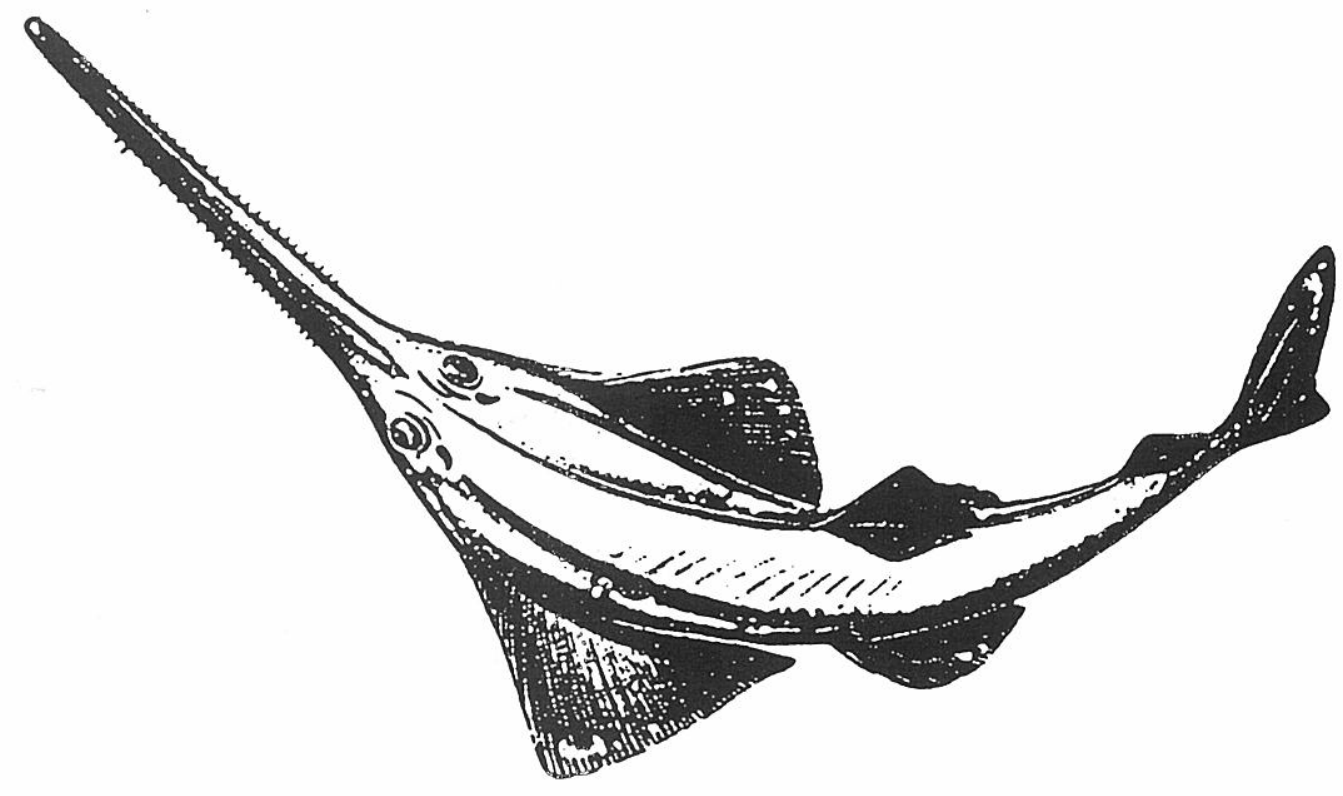

Figure 1. Outline restoration of a Cretaceous sclerorhynchid sawfish. Redrawn from Frickhinger (1991) with permission.

Santonian of Lebanon. Weiler (1935) attributed isolated remains from the Cenomanian of Egypt as Peyeria libyca (Weiler, 1935) to pristid sawfishes (Pristiformes). However, these remains may represent more likely dermal thorns of any batoid (Cappetta, 1987). Pristids first appeared in the Palaeogene.

The aim of the present paper is to give a review of the paleobiology and paleogeographic distribution of sclerorhynchids and to present the oldest sclerorhynchid sawfish remains from Spain.

\section{PALEOBIOLOGY OF SCLERORHYNCHID SAWFISHES}

Sclerorhynchid sawfishes most likely occupied an ecological niche equivalent to that presently filled by pristid sawfishes and pristiophorid sawsharks (Welton and Farish, 1993). Like Recent pristids, sclerorhynchids were mainly sluggish bottom dwellers of shallow nearcoast waters, of bays and estuaries. Some were probably capable to ascend into freshwaters like Recent pristids that intrude the Nicaragua lake and freshwaters in Sambesi (e.g., Bigelow and Schroeder, 1953). The sclerorhynchid sawfishes Ischyrhiza Leidy, Dalpiazia Checchia-Rispoli and Schizorhiza Weiler were interpreted as nectonic fishes by Cappetta $(1972,1980)$. Most sclerorhynchids show a rather limited distribution. But at least four genera are cosmopolitan and some others are distributed over large distances (Tab. 1). Werner (1989) considered the sclerorhynchids Micropristis Cappetta, 1980 and Libanopristis Cappetta, 1980 as batoids of deeper water regions whereas Onchopristis Stromer, 1917, Baharipristis Werner, 1989 and Marckgrafia Weiler, 1935 were confined to coastal waters. Branch and Mosley (1997) concluded that sclerorhynchids frequented warm, shallow tropical marine environments like Recent pristids.

The function of the rostral blade of sclerorhynchids (Fig. 2) is still discussed. The assumption that it was used to probe into sand or mud to dig up small invertebrates or fish whatever they were able to catch like Recent pristids may do nowadays is not verified. Only few rostral spines of sclerorhynchids show the typical abrasion pattern as found on rostral spines of Recent pristids (Fig. 3). This may be due to the early loss of damaged spines (Slaughter and Springer, 1968) or that the rostral blade was not used for grubbing in sand or mud. Another possibility is that sclerorhynchids mainly used the rostral blade to paralyze or kill small fishes or invertebrates like crays by slashing the blade to and fro in schools of fish (e.g., Welton and Farish, 1993). But Recent pristids do not show this adaption. They catch prey like other sharks and rays without the help of the rostral blade (Schultze, pers. com.). More convincing is the assumption that the rostral blade represents a powerfull weapon.

The oral dentition is of crushing-type ("type ecraseur" of Cappetta, 1986) indicating shelled food like bivalves or crustaceans in addition to small fish.

\section{ONCHOPRISTIS STROMER IN THE LOWER CRETACEOUS OF ALCAINE, EASTERN SPAIN}

Onchopristis is common in the Lower and Middle Cretaceous of Europe, North Africa and the U.S.A. The oldest sclerorhynchid sawfish remains come from marly sediments of early Barremian age near the village of Alcaine, Province of Teruel of Spain and consist of isolated oral teeth (Fig. 4; Kriwet, 1999). The vertebrate bearing strata of Alcaine are located within the Oliete subbasin in the central Iberian Ranges. The sedimentation of the basin was mainly alluvial and continental with 


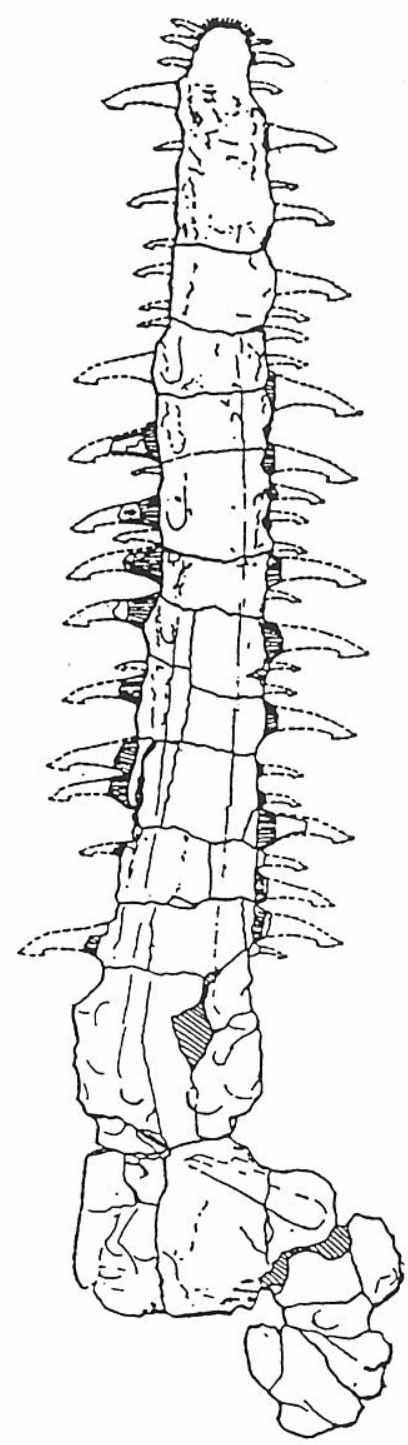

Figure 2. Rostral blade of Onchopristis numidus Haug, 1905 from the Cenomanian of Egypt. Taken from Arambourg (1940).

Wealden facies interbedded with shallow marine, lagoonal sediments. The teeth were recovered in marine influenced strata. This interpretation is also confirmed by the occurrence of a diverse near-coast selachian fauna and teeth of two semi-aquatic crocodilians, Bernissartia and Theriosuchus.

Onchopristis is characterized by a rather thick rostral blade in comparison to other sclerorhynchids. The teeth are cuspidate with a typical crusiform morphology. The root is of batoid type. The thick rostral blade and the tooth morphology are plesiomorphic within sclerorhynchids (Kriwet, in prep.).

The material from Alcaine comprises five isolated oral teeth which are attributed to Onchopristis dunklei McNulty and Slaughter (Fig. 4, A-F) (Measurements: mesio-distal width of teeth: 0.7-1.1 mm; height of teeth: 0.75-1.2 mm) and Onchopristis sp. (Fig. 4, G-H) (Measurements: mesio-distal width of tooth crown: 0.73 $\mathrm{mm}$; height of tooth crown: $1.35 \mathrm{~mm}$ ).

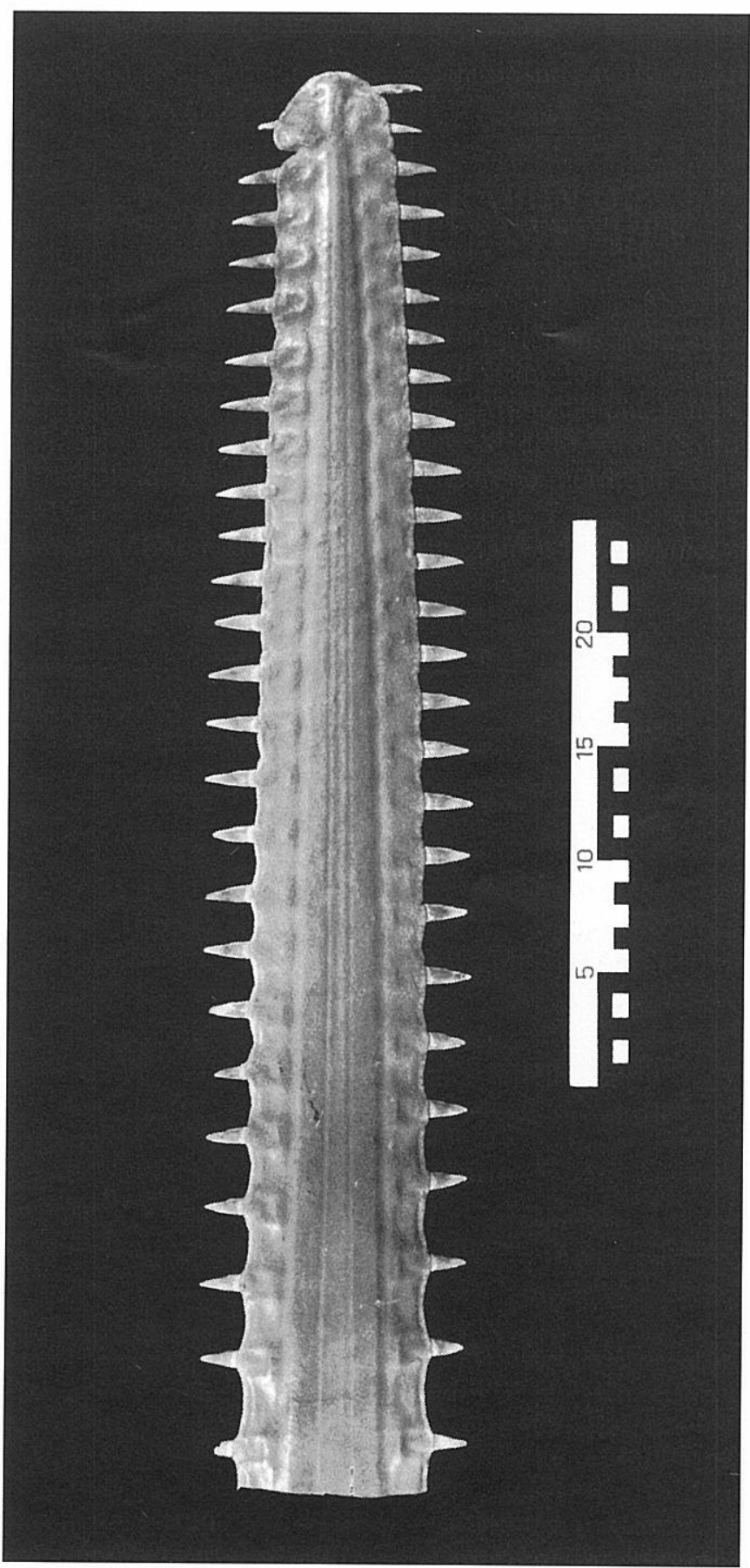

Figure 3. Rostral blade of the Recent pristid sawfish Pristis pectinata Latham.

\section{PALEOBIOGEOGRAPHY OF SCLERORHYNCHID SAWFISHES}

To reconstruct the paleobiogeography of sclerorhynchid sawfishes nearly 200 citations from about 90 papers were considered. The distribution was coded stratigraphically to different areas: Arabia, India, Eurasia (mainly Kazakhstan), Near and Middle East (Syria, Israel, Iraq, Lebanon, Jordania), Europe, northern Africa (Marocco, Algeria, Tunisia, Lybia, Egypt), Africa (Angola, Cabinda, Niger, Nigeria, Zaire), North America 


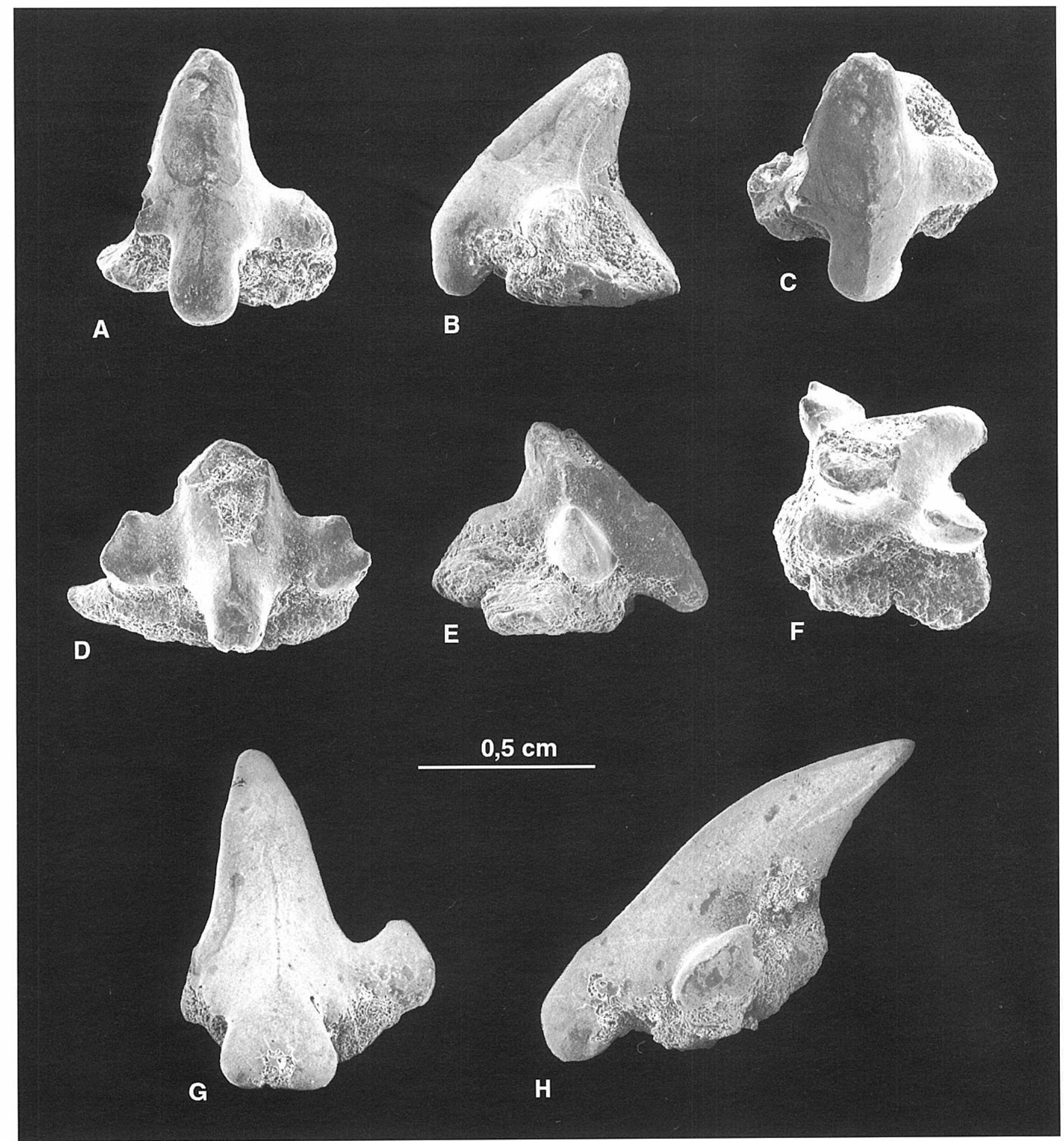

Figure 4. Isolated oral teeth of Onchopristis Stromer, 1917 from the lower Barremian of Alcaine, Province of Teruel. A-C: Anterior tooth of Onchopristis dunklei. A: Labial view. B: Lateral view. C: Occlusal view. D-F: Lateral tooth Onchopristis dunklei. D: Labial view. E: Lateral view. F: Occlusal view. G-H: Tooth of Onchopristis sp. G: Labial view. H: Lateral view.

(U.S.A. and Canada), South America (Brazil, Bolivia, Chile, Ecuador, Peru), and the Pacific area (Japan and New Zealand). The summary of this investigation is shown in Tab. 1 and in Appendix 1. The qualitative distribution of sclerorhynchid genera is shown in Fig. 5. Unfortunately, space preludes an extensive discussion of the distributional patterns of sclerorhynchids. Therefore, we give only some general conclusions.

The oldest known sclerorhynchid, Onchopristis, is from the lower Barremian of Europe. Other Early Cretaceous records are from the Aptian-Albian boundary of Texas (Onchopristis praecursor and Onchopristis sp.; 


\begin{tabular}{|l|c|c|c|c|c|}
\hline Genus & Europe & Greenland & Near East & North Africa & Africa \\
\hline Ankistrorhynchus & $\mathrm{Sa}$ & & & & \\
\hline Baharipristis & & & & $\mathrm{Ce}$ & \\
\hline Borodinopristis & & & & & \\
\hline Ctenopristis & & & $\mathrm{Ma}$ & $\mathrm{Ma}, \mathrm{Th} ?^{*}$ & $\mathrm{Ma}$ \\
\hline Dalpiazia & & & $\mathrm{Ma}$ & $\mathrm{Ma}$ & $\mathrm{Ma}$ \\
\hline Ganopristis & $\mathrm{Ma}$ & & $\mathrm{Ca} / \mathrm{Ma}$ & $\mathrm{Ma}$ & \\
\hline Ischyrhiza & $\mathrm{Sa}, \mathrm{Pa}^{*}$ & & & & $\mathrm{Ma}$ \\
\hline Libanopristis & & & $\mathrm{Ce}$ & & \\
\hline Marckgrafia & & & & $\mathrm{Ce}$ & \\
\hline Micropristis & $\mathrm{Sa}, \mathrm{Ca} ?$ & & $\mathrm{Ce}$ & & \\
\hline Onchopristis & $\mathrm{Ba}, \mathrm{Ce}$ & $\mathrm{Ce} / \mathrm{Tu}(?)$ & & $\mathrm{Al}, \mathrm{Ce}, \mathrm{Sa}, \mathrm{Ca}$ & \\
\hline Onchosaurus & $\mathrm{Sen}$ & & & $\mathrm{Sa}$ & $\mathrm{Tu}, \mathrm{Sen}$ \\
\hline cf. Onchosaurus & & & & & \\
\hline Plicatopristis & & & $\mathrm{Ma}$ & $\mathrm{Ma}$ & \\
\hline Pucapristis & & & & & \\
\hline Schizorhiza & $\mathrm{Ma}, \mathrm{Pa}{ }^{*}$ & & $\mathrm{Ma}, \mathrm{Ca}$ & $\mathrm{Sen}$ & \\
\hline Sclerorhynchus & $\mathrm{Co}, \mathrm{Ca}$ & & & & \\
\hline Sclerorhynchidae indet. & & & $\mathrm{Ma}$ \\
\hline
\end{tabular}

\begin{tabular}{|l|c|c|c|c|c|c|}
\hline Genus & North America & South America & Pacific area & Eurasia & India & Arabia \\
\hline Ankistrorhynchus & $\mathrm{Ca}, \mathrm{Ma}$ & & & & & \\
\hline Baharipristis & & & & & & \\
\hline Borodinopristis & $\mathrm{Sa}, \mathrm{Ca}$ & & & & & \\
\hline Ctenopristis & & & & & & \\
\hline Dalpiazia & & & & & & \\
\hline Ganopristis & & & & & & \\
\hline Ischyrhiza & $\mathrm{Ce} / \mathrm{Tu}-\mathrm{Ma}, \mathrm{Mo} ?^{\star}$ & $\mathrm{Ca}, \mathrm{Ma}$ & $\mathrm{Co} / \mathrm{Sa}$ & $\mathrm{Tu}-\mathrm{Ca}$ & & \\
\hline Libanopristis & & & & & & \\
\hline Marckgrafia & & & & & & \\
\hline Micropristis & & & & & & \\
\hline Onchopristis & $\mathrm{Ap} / \mathrm{Al}, \mathrm{Ce}, \mathrm{Ca}$ & & & & Upp. Cret. & \\
\hline Onchosaurus & $\mathrm{Ca}$ & $\mathrm{Tu}, \mathrm{Sen}$ & & & & \\
\hline cf. Onchosaurus & $\mathrm{Sa}$ & & & & & \\
\hline Plicatopristis & & & & & & \\
\hline Pucapristis & & $\mathrm{Ma}, \mathrm{Pa}$ ? $^{* *}$ & & & & \\
\hline Schizorhiza & $\mathrm{Ma}$ & $\mathrm{Ca}, \mathrm{Ma}$ & & & & \\
\hline Sclerorhynchus & $\mathrm{Tu} / \mathrm{Co}, \mathrm{Ce}, \mathrm{Ca}, \mathrm{Ma}$ & $\mathrm{Ca}$ & $\mathrm{Ca} / \mathrm{Ma}$ & & & Upp. Cret. \\
\hline Sclerorhynchidae indet. & & $\mathrm{Ca} / \mathrm{Ma}$ & & & & \\
\hline
\end{tabular}

\begin{tabular}{|c|c|c|}
\hline Abbreviations: & $\begin{array}{l}\mathrm{Ba}=\text { Barremian } \\
\mathrm{Ap}=\text { Aptian } \\
\mathrm{Al}=\text { Albian } \\
\mathrm{Ce}=\text { Cenomania } \\
\mathrm{Tu}=\text { Turonian } \\
\mathrm{Co}=\text { Coniacian } \\
\mathrm{Sa}=\text { Santonian }\end{array}$ & $\begin{array}{l}\mathrm{Ca}=\text { Campanian } \\
\mathrm{Ma}=\text { Maastrichtian } \\
\mathrm{Mo} ?=\text { Montian } \\
\mathrm{Pa}, \mathrm{Pa} ?=\text { Paleocene } \\
\text { Sen = Senonian } \\
{ }^{\star}=\text { reworked } \\
{ }^{\star \star}=\text { no sclerorhynchid }\end{array}$ \\
\hline
\end{tabular}

Table 1. Paleogeographic and stratigraphic distribution of sclerorhynchid sawfishes. 


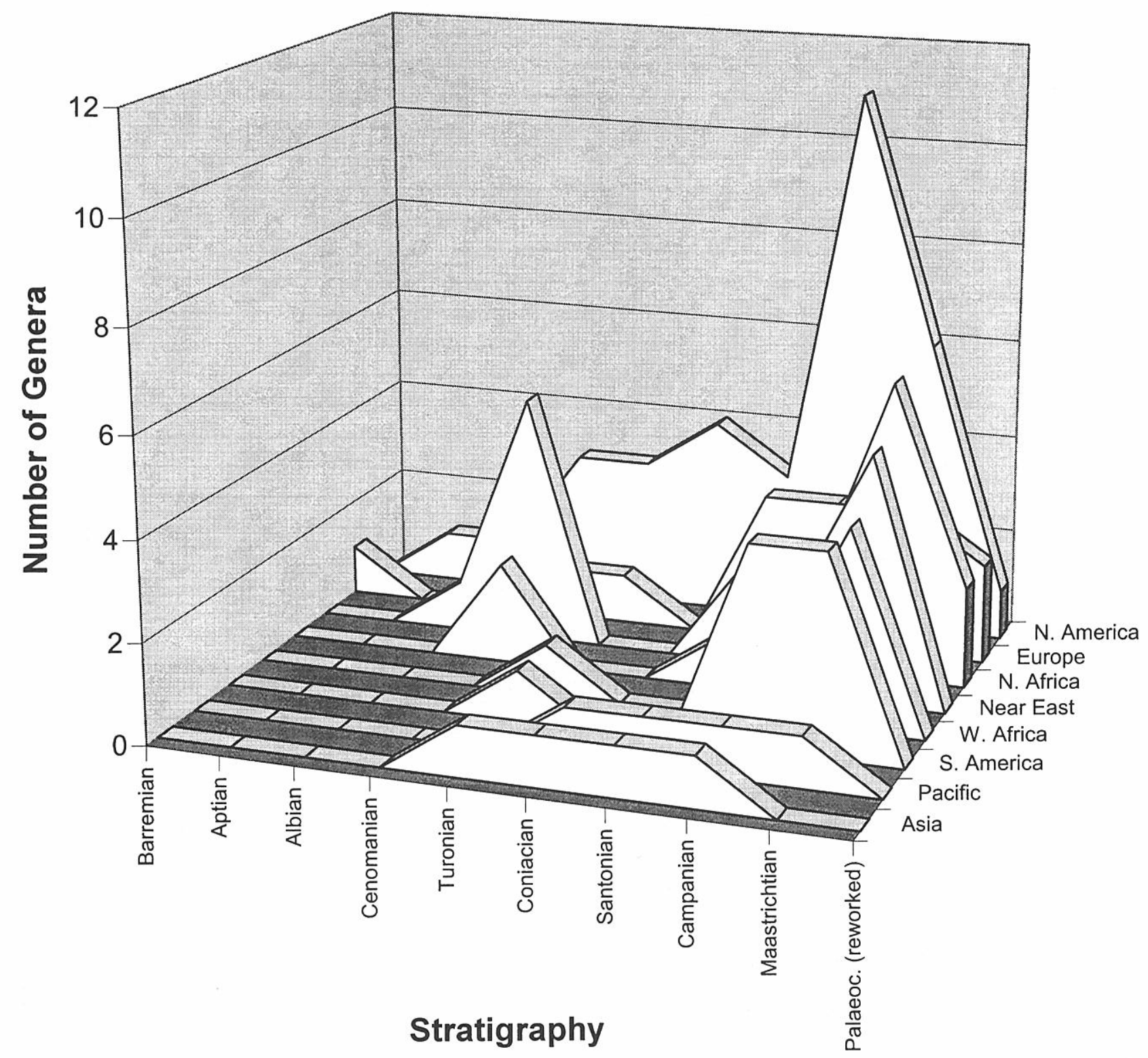

Figure 5. Qualitative distribution of sclerorhynchid sawfish genera. Numbers on the y-axis represent numbers of genera.

Thurmond, 1971, 1974; Cappetta et al., 1993; Branch and Mosley, 1997). Onchopristis is also common in upper Albian and Cenomanian strata of northern Africa (Fig. 6), in the Lower and Upper Cretaceous of the U.S.A., rocks close to the Cenomanian-Turonian boundary of Greenland, and in the Cenomanian of Egypt (e.g., Cappetta and Case, 1999; Haug, 1905; Slaughter and Steiner, 1968; Stromer, 1925; Werner, 1989). Onchopristis was assumed to be the only representative of sclerorhynchid sawfishes in the Early Cretaceous. Nevertheless, a rostral spine identified as sclerorhynchid remain was recently reported from the upper Albian of England (Underwood and Mitchell, 1999). The specimen differs from rostral spines of Onchopristis. Moreover, the peculiar morphology is not characteristic for sclerorhynchid rostral spines (Cappetta, pers. com.).

In the Cenomanian, sclerorhynchid sawfishes are more diverse. At least six sclerorhynchid genera are known in the Cenomanian of France (Onchopristis), Lebanon (Libanopristis, Micropristis), North Africa (Baharipristis, Marckgrafia, Onchopristis), and North America (Onchopristis, Sclerorhynchus) (e.g., Cappetta, 1980; Cappetta, 1987; Werner, 1989; Case, 1991).

Sclerorhynchid sawfish records from the Turonian and Coniacian are rather rare. Most common is Ischyrhiza. Other Turonian and Coniacian sclerorhynchids are Onchopristis, Onchosaurus and Sclerorhynchus (e.g., Dunkle, 1951; Cappetta and Case 1999). The oldest record of Ischyrhiza, perhaps the most succesful sclerorhynchid, is from the CenomanianTuronian boundary of Arizona (Williamson et al., 1993). Ischyrhiza is a common element of Upper Cretaceous elasmobranch faunas of the U.S.A. Outside North America Ischyrhiza species were found in the Coniacian/Santonian of Japan (Uyeno and Hasegawa, 1986; Goto et al., 1996), the Campanian of northwestern 


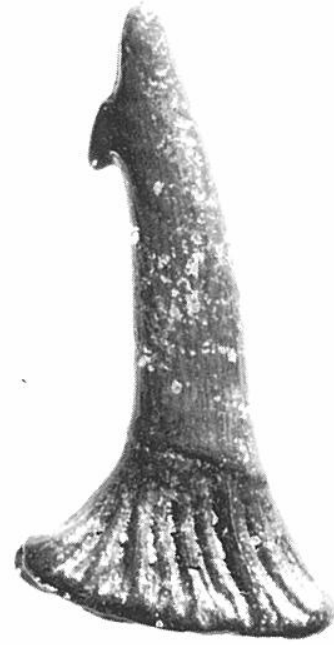

Figure 6. Rostral spine of Onchopristis numidus Haug, 1905 from the Cenomanian of Morocco, dorsal view. Scale bar in millimeter.

Germany, described as Sclerorhynchus germaniae by Albers and Weiler (1964), the Santonian of France (Cappetta, 1981), the Maastrichtian of Bolivia (Cappetta, 1975), and the Maastrichtian of Niger (Cappetta, 1972).

The record of sclerorhynchid sawfishes from the Santonian seems to be rather incomplete. Only seven identified species and a specimen of uncertain affinity were reported from five countries (Appendix 1). One of these species, Sclerorhynchus atavus, is represented by several well preserved specimens from limestones of Lebanon (Woodward, 1892; Cappetta, 1980, 1987).

In the Campanian, sclerorhynchid sawfishes are known mainly from the U.S.A. Other Campanian sclerorhynchids were reported from Kazakhstan (Glikman, 1967), Germany (Müller, 1989), Israel (Lewy and Cappetta, 1989) and from Peru (Mourier et al., 1988). There are about 30 regional citations in the Campanian indicating the occurence of at least 11 species and several specimens without specific determination.

The Maastrichtian marks the peak of the distribution and evolution of sclerorhynchids. At least 15 species belonging to nine genera are cited from a total of 42 areas. Unfortunately, there are several citations without specific identification of the remains or inaccurate stratigraphic assignments. These citations were not further considered.

Recently, Smith (1999) documented an isolated rostral spine of Ischyrhiza sp. and an isolated oral tooth of Sclerorhynchus sp. cf. S. pettersi Case and Cappetta, 1997 from upper Paleocene strata of Belgium. However, this rostral spine is reworked from Upper Cretaceous strata (Cappetta, pers. com.). If the stratigraphy is correct these remains indicate the survival of sclerorhynchids across the Cretaceous/Tertiary boundary.

North America (including Canada and the U.S.A.) reveals the greatest diversity (about 62 citations from the uppermost Aptian to the Maastrichtian, 27 citations alone in Texas), followed by North Africa with about 23

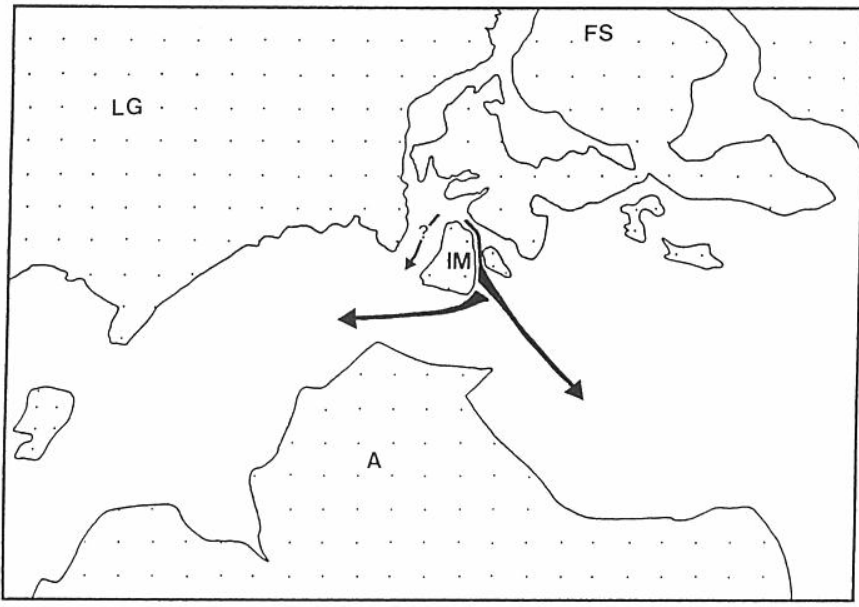

Figure. 7.Barremian-Hauterivian paleogeographic map showing the early diversification of sclerorhynchid sawfishes. The centre of diversification is located somewhere in Middle Europe. During the Lower Cretaceous sclerorhynchids spread along the coast of Iberia to the south and west. Base map from Smith et al. (1994). $\mathbf{A}=$ Africa, $\mathbf{F S}=$ Fennosarmatia, $\mathbf{I M}=$ Iberian Massif, $\mathbf{L G}=$ Laurentia-Greenland.

citations ranging from the upper Albian to the Maastrichtian.

In contrast, only a single species was reported from the following regions: Arabian Peninsula (Sclerorhynchus sp., Upper Cretaceous); Algeria, North Africa [Onchopristis numidus (Haug, 1905), upper Albian]; Cabinda, Africa (Ctenopristis nougareti Arambourg, 1940, Maastrichtian); Nigeria, Africa (Schizorhiza stromeri Weiler, Maastrichtian); Alberta, Canada (Ischyrhiza mira Leidy, Campanian); North Carolina, U.S.A. (Ischyrhiza mira Leidy, Maastrichtian); South Dakota, U.S.A. (Ischyrhiza avonicola Estes, Turonian); Brazil, South America [Onchosaurus pharao (Dames), Senonian]; Chile, South America (Schizorhiza stromeri Weiler, 1930, Maastrichtian); Ecuador, South America (Onchosaurus cf. radicalis, Turonian) and from New Zealand, Pacific area (Sclerorhynchus? sp. identified as Onchopristis dunklei praecursor by Keyes (1977), Campanian-Maastrichtian). Eurasia, Asia and the Pacific area are poor in sclerorhynchid sawfish remains. But this may represent a collecting bias.

The occurrences of sclerorhynchid sawfishes can be divided into three zoogeographic zones (Tab. 2): 1. Cosmopolitan sawfishes: Ischyrhiza, Onchopristis, Onchosaurus and Sclerorhynchus. 2. Endemic Laurasian (North America, Europe and Eurasia and Asia north of the Himalaya) sawfishes: Ankistrorhynchus and Borodinopristis. 3. Endemic Gondwanan (South America, Africa, Madagaskar, India, Arabia, Malaya, Australia, Antarctica) sawfishes: Baharipristis, Ctenopristis, Libanopristis, Marckgrafia, Micropristis (occurs probably also in the Upper Cretaceous of Europe, see Appendix 1, Cappetta, 1987), Plicatopristis Cappetta, 1991 and Pucapristis Schaeffer. Ganopristis Arambourg 


\begin{tabular}{|c|c|c|}
\hline Gondwana sawfishes & Laurasian sawfishes & Cosmopolitan sawfishes \\
\hline Baharipristis & Ankistrorhynchus & Ganopristis \\
\hline Ctenopristis & Borodinopristis & Ischyrhiza \\
\hline Libanopristis & & Onchopristis \\
\hline Marckgrafia & & Onchosaurus \\
\hline Micropristis & & Schizorhiza \\
\hline Plicatopristis & & Sclerorhynchus \\
\hline Pucapristis & &
\end{tabular}

Table 2. Zoogeography of sclerorhynchid sawfishes.

is mainly restricted to Africa but was also found in the Maastrichtian of the Netherlands (Casier, 1964) and Northern Spain (Cappetta and Corral, 1999). In addition, Dalpiazia, mainly known from Gondwana, also occurs in the Maastrichtian of Northern Spain (Cappetta and Corral, 1999). The mainly Gondwanan sclerorhynchid Schizorhiza was also reported from the Maastrichtian of Texas, U.S.A. (Dunkle, 1948). Therefore, both genera can be assigned to the cosmopolitan group.

Cosmopolitan sawfishes are defined as group with distribution on the northern and southern hemisphere. About $37.5 \%$ of all sclerorhynchid genera belong to this group (including Ganopristis and Schizorhiza). Ischyrhiza is a typical faunal element of the North American Gulf coastal plains and the interior seaway, but it is also known from Europe, Japan and South America. Half of all known sclerorhynchid sawfishes $(=50 \%)$ can be attributed to the Gondwanan group.

There is only minor evidence favouring an interchange between South America and Africa. A pattern of sympatry emerges in the Turonian, Campanian and Maastrichtian if the records of Ischyrhiza, Onchosaurus, Schizorhiza and Sclerorhynchus are considered.

Endemic sawfishes of North and South America are Borodinopristis and Pucapristis respectively (Case, 1987;
Cappetta, 1987). Pucapristis may have even biostratigraphic value. Other Gondwanan sawfishes of South America are Onchosaurus (Turonian of Ecuador and Maastrichtian of Brasil, Cappetta, 1987) and to some extend Schizorhiza (Maastrichtian of Bolivia). But Schizorhiza also occurs in Iraq and Jordania (JK, pers. obs.).

Africa shows the greatest diversity of endemic sawfishes. About $21 \%$ can be attributed to this group.

Only two sclerorhynchids have a Laurasian distribution pattern ( $=12.5 \%$; see above).

Sclerorhynchid sawfishes are rarely known from the Middle East (Iraq, Jordan, Lebanon), India, Japan and from Eurasia, especially from the former U.S.S.R. Nessov (1997) indicates the occurrence of a new species of Ischyrhiza, I. serra, in the upper Turonian and Coniacian and perhaps in the Santonian of Uzbekistan. Probably a new species of Ischyrhiza was found in the lower Campanian of Kazakhstan and identified by Glikman (1980) as Onchosaurus sp. (Averianov, pers. com.). Recently, a first summary of Syrian selachians from the uppermost Cretaceous was published by Bardet et al. (2000) including references on sclerorhynchid sawfishes.

\section{CONCLUSIONS}

Sclerorhynchid sawfishes are known from many Lower and Upper Cretaceous marine fossil localities. They are batoids with a dorso-ventrally flattened body, with pectorals attached to the head and a long hypertrophic rostrum armed with lateral rows of specific spines. In comparison with Recent pristid sawfishes it is assumed that they mainly lived near the bottom in shallow water with sandy or muddy substrate. The rostral blade was certainly used in many ways. It is assumed that

\begin{tabular}{|c|c|c|c|c|c|c|c|c|c|}
\hline Stratigraphy & Europe & Greenland & Near East & North Africa & Africa & North America & South America & Pacific area & Eurasia \\
\hline Paleocene & Is?, S? & & & & & & & & \\
\hline Maastrichtian & $\mathrm{Ga}, \mathrm{S}$ & & $\mathrm{Ct}, \mathrm{Ga}, \mathrm{Sc}, \mathrm{Da}, \mathrm{Pl}$ & $\mathrm{Ba}, \mathrm{Ct}, \mathrm{Da}, \mathrm{Ga}, \mathrm{PI}, \mathrm{Sc}$ & $\mathrm{Ct}, \mathrm{Da}, \mathrm{Is}, \mathrm{Sc}$ & $\mathrm{Ma}, \mathrm{Is}, \mathrm{Sc}, \mathrm{S}$ & $\mathrm{Is}, \mathrm{Pu}, \mathrm{Sc}$ & $\mathrm{S}$ & \\
\hline Campanian & Mi? & & $\mathrm{Ga}, \mathrm{S}$ & \begin{tabular}{|c|}
0 \\
\end{tabular} & & An, Bo, Is, O, On, S & Is?, On, S & $\mathrm{s}$ & Is \\
\hline Santonian & An, Is, Mi? & & $s$ & $0,0 n$ & & Bo, Is, On? & & Is & Is \\
\hline Coniacian & & & & & & Is, S & & Is & Is \\
\hline Turonian & & 0 & & & On & Is, S & On & & Is \\
\hline Cenomanian & 0 & 0 & $\mathrm{Li}, \mathrm{Mi}$ & $\mathrm{Ma}, \mathrm{O}$ & & Is, O, S & & & \\
\hline Albian & Scl & & & 0 & & 0 & & & \\
\hline Aptian & & & & & & 0 & & & \\
\hline Barremian & 0 & & & & & & & & \\
\hline Hauterivian & 0 & & & & & & & & \\
\hline
\end{tabular}

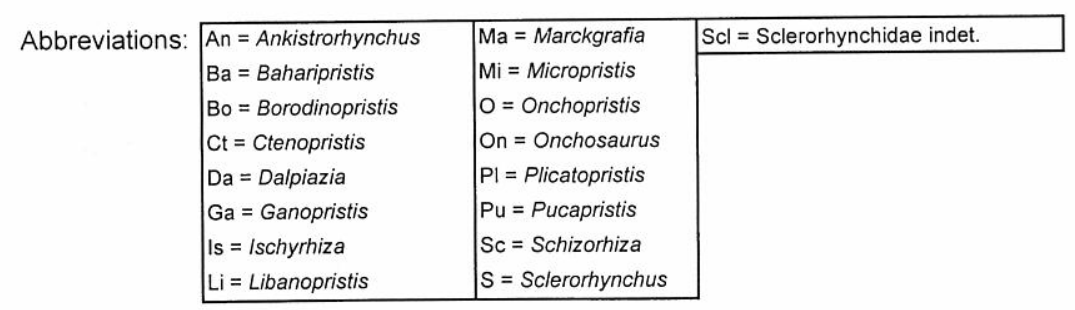

Table 3. Distribution of sclerorhynchid sawfishes showing similarities between areas. 
it was used to grub for food into the sediment or to slash it into schools of fish to kill the prey. However, the spines show minor or no abrasion compared to rostral spines of extant pristids. This may contradict the interpretation that the rostral blade was used to grub into the sediment. Additional, the blade certainly also served as a weapon for defense and/or offense. The oral tooth morphology indicates that they fed on small fish and shelled invertebrates like crustaceans or echinoderms like most Recent rajiform batoids.

An analysis of the biogeographical distribution of fossil organisms may be best carried out by calculating faunal similarities for different areas using similarity coefficients (e.g., Simpson index, Jaccard index, Johnson index). But to obtain useful and good results the faunal compositions should include many different species (> $25)$. For the batoid group discussed in this paper the application of such statistical approaches is not useful as the faunal compositions of the investigated areas are too small on specific level (see Appendix 1).

The earliest known sclerorhynchid representative belongs to the genus Onchopristis and comes from the Hauterivian of England and Barremian of Spain (Tab. 3). Onchopristis seems to be absent in the Aptian and Albian of Europe. But this may be due to a collecting bias. The only Albian sclerorhynchid of Europe was reported in open nomenclature from England. Outside Europe, Onchopristis is found in the Aptian and Albian to Cenomanian of Texas (U.S.A.). The Cenomanian represents the first peak of sclerorhynchid distribution (Tab. 3). Seven species belonging to seven genera are knwon from Europe, Near East, North Africa and North America. The Aptian/Albian and Cenomanian records of sclerorhynchids from the Near East, North Africa and North America prove a rapide diversification of sclerorhynchids during the Early Cretaceous and Cenomanian. The centre of origin and diversification is located somewhere in the Tethys area of Middle Europe (Fig. 7). So far, the ancestor of sclerorhynchids is not known.

The Cenomanian of Egypt and Lebanon is marked by several endemic genera (e.g., Baharipristis, Marckgrafia, Libanopristis). The most succesful sclerorhynchid, Ischyrhiza, first appeared in the Cenomanian of North America and is quite common in the Turonian and Coniacian of the western Tethys and the Interior Sea way of North America. The rather rare records of Coniacian sclerorhynchids (almost all belong to Ischyrhiza) are related to the absence of possible sediments to collect. The Campanian and Maastrichtian represents the second peak of sclerorhynchid distribution (Tab. 3). Sclerorhynchids are restricted mainly to the Cretaceous period. The rare occurrences in the Lower Tertiary are either reworked specimens (e.g., Ctenopristis nougareti from the Thanetian of Marocco and Ischyrhiza mira from the Montian of Texas) or belong to other elasmobranchs, e.g., Pucapristis? standhardtae Williamson and Lucas, 1993 from the Paleocene of New Mexico, U.S.A., which may belong in fact to an orectolobid shark and Sclerorhynchus palaeocenicus from the Paleocene of Marocco (Herman, 1973) which must be attributed to
Pristiophorus (Cappetta, 1987). Reworked remains of two sclerorhynchid sawfishes were recently reported from the upper Paleocene of Belgium (Smith, 1999). The radiation of sclerorhynchids in the Cretaceous is supported by high sea levels during transgressive phases (e.g., Cenomanian transgression), lack of barriers to migration, and low latitudinal gradients during the Cretaceous period. Separated Boreal and Tethyal elasmobranch faunal provinces were postulated by Werner (1989) based on the distribution of batoid species (contra Williamson et al., 1993). Our investigations also do not confirm the results of Werner (1989).

\section{ACKNOWLEDGEMENTS}

This paper resulted from a study of Early Cretaceous elasmobranchs from eastern Spain. We are indebted to Prof. Dr. G. Meléndez and Prof. Dr. M. Aurell (both Zaragoza) for the permission for field work. The study benefitted from discussions during the XIV Jornadas de Paleontologia in Tenerife, Canarian Islands, in 1998. We thank Dr. A. Averianov (St. Petersburg) for information on sclerorhynchid occurrences in the former U.S.S.R. and the Mergus Verlag for permission to reproduce the sclerorhynchid restoration shown in Fig. 1. Dr. R. Soler (Madrid) is thanked for the translation of the Spanish abstract. We also wish to thank Prof. Dr. H.-P. Schultze (Berlin) for his critical reading of the manuscripte and many helpful suggestions. Dr. H. Cappetta (Montpellier), Dr. R. Soler (Madrid), and an anonymous reviewer are acknowledged for intensive and helpful comments on the manuscript, of which it has been improved. The participitation in the Tenerife meeting was possible through financial support by U. Tschudi-Steinhardt (Switzerland).

\section{REFERENCES}

Albers, H. und Weiler, W. 1964. Eine Fischfauna aus der oberen Kreide von Aachen und neuere Funde von Fischresten aus dem Maestricht des angrenzenden belgisch-holländischen Raumes. Neues Jahrbuch für Geologie und Paläontologie, Abhandlungen, 120, 1-33.

Arambourg, C. 1940. Le groupe des ganopristinés. Compte rendu sommaire et bulletin de la société géologique de France, 5. Sér., 10, 127-146.

Bardet, N., Cappetta, H., Pereda Suberbiola, X., Mouty, M., Al Maleh, A.K., Ahmad, A.M., Khrata, O. and Gannoum, N. 2000. The marine vertebrate faunas from the Late Cretaceous phosphates of Syria. Geological Magazine, 137, 269-290.

Bigelow, H.B. and Schroeder, W.C. 1953. Fishes of the Western Atlantic. No 1. Part 2. Sawfishes, Guitarfishes, Skates and Rays. Sears Foundation for marine research, Yale. 588 pp.

Branch, J.R. and Mosley, J.L. 1997. The oldest sclerorhynchid sawfish (Rajiformes: Sclerorhynchidae) from the Lower Cretaceous of Texas. The Texas Journal of Science, 49, 199-206. 
Cappetta, H. 1972. Les poissons Crétacés et Tertiaires du Bassin des Iullemmeden (République du Niger). Palaeovertebrata, 5, 179-251.

Cappetta, H. 1974. Sclerorhynchidae nov. Fam., Pristidae et Pristiophoridae: un exemple de parallélisme chez les sélaciens. Compte rendu de l'Académie des Sciences, 278, 225-228.

Cappetta, H. 1975. Sur quelques sélaciens nouveaux du Crétacé supérieur de Bolivie. Geobios, 8, 5-24.

Cappetta, H. 1980. Les sélaciens du Crétacé supérieur du Liban. II. Batoides. Palaeontographica, A 168, 149-229.

Cappetta, H. 1981. Sur la découverte des genres Ischyrhiza et Ptychotrygon (Selachii, Batomorphii) dans le Crétacé supérieur de Vendée (France). Geobios, 14, 807-812.

Cappetta, H. 1986. Types dentaires adaptifs chez les sélaciens actuels et post-paléozoiques. Palaeovertebrata, 16, 57-76.

Cappetta, H. 1987. Chondrichthyes II. Mesozoic and Cenozoic Elasmobranchii. In: Handbook of Paleoichthyology, Vol. 3B (Ed. H.-P. Schultze). Gustav Fischer Verlag, Stuttgart-New York, 1-193.

Cappetta, H. 1991. Découvertes de nouvelles faunes de sélaciens (Neoselachii) dans les phosphates maastrichtiens de la Mer Rouge, Egypte. Münchner geowissenschaftliche Abhandlungen, A, 19, 17-56.

Cappetta, H. et Case, G.R. 1999. Additions aux faunes de sélaciens du Crétacé du Texas (Albien supérieur Campanian). Palaeo Ichthyologica, 9, 5-111.

Cappetta, H. and Corral, J.C. 1999. Upper Maastrichtian selachians from the Condado de Treviño (BasqueCantabrian Region, Iberian Peninsula). Estudios del Museo de Ciencias naturales de Alava, Número especial $1,14,339-372$.

Cappetta, H., Duffin, C. and Zidek, J. 1993. Chondrichthyes. In: The Fossil Record 2 (Ed. M.J. Benton). Chapman \& Hall, London, 593-609.

Case, G.R. 1987. Borodinopristis schwimmeri, a new ganopristine sawfish from the Upper Blufftown Formation (Campanian) of the Upper Cretaceous of Georgia. Bulletin of the New Jersey Academy of Sciences, 32, 25-33.

Case, G.R. 1991. Selachians (sharks) from the Tupelo Tongue of the Coffee Sand (Campanian, Upper Cretaceous) in northern Lee County, Mississippi. Mississippi Geology, 11, 1-8.

Case, G.R. and Cappetta, H. 1997. A new selachian fauna from the Late Maastrichtian of Texas (Upper Cretaceous/Navarroan; Kemp Formation). Münchner geowissenschaftliche Abhandlungen (A), 34, 131-189.

Casier, E. 1964. Présence de Ganopristinae dans la Glauconie de Lonzée et dans le Tuffeau de Maestricht. Bulletin de l'Institut royal des sciences naturelles de Belgique, 40, 1-26.

Dunkle, D.H. 1948. On two previously unreported selachians from the Upper Cretaceous of North America. Journal of the Washington Academy of Science, 38, 173176.

Dunkle, D.H. 1951. New western hemisphere occurrences of fossil selachians. Journal of the Washington Academy of Science, 41, 344-347.
Frickhinger, K.A. 1991. Fossilien Atlas Fische. Mergus Verlag, Melle. 1088 pp.

Glikman, L.S. 1967. Subclass Elasmobranchii. In: Fundamentals of Paleontology (Ed. A. Orlov). S. Monson, Jerusalem, 292-411 (Translated from Russian by the Israel Program for Scientific Translations).

Glikman, L.S. 1980. Evolution of Cretaceous and Cenozoic lamnoid sharks. Nauka, Moscow. 248 pp. (In Russian).

Goto, M., Uyeno, T. and Yabumoto, Y. 1996. Summary of Mesozoic elasmobranch remains from Japan. In: Mesozoic Fishes - Systematics and Paleoecology (Eds. G. Arratia \& G. Viohl). Verlag Dr. Friedrich Pfeil, München, 73-82.

Haug, E. 1905. Paléontologie. In: Documents scientifiques de la mission sahariennne. Mission Foureau-Lamy (Ed. F. Foureau), Masson, Paris, 751-832.

Herman, J. 1973. Contribution à la connaissance de la faune ichthyologique des phosphates du Maroc. Annales de la Société géologique de Belgique, 95, 271-284.

Keyes, I.W. 1977. Records of the northern hemisphere Cretaceous sawfish genus Onchopristis (Order Batoidea) from New Zealand. New Zealand Journal of Geology and Geophysics, 20, 263-272.

Kriwet, J. 1999. Neoselachier (Pisces, Elasmobranchii) aus der Unterkreide (unteres Barremium) von Galve und Alcaine (Spanien, Provinz Teruel). Palaeo Ichthyologica, 9, 113-142.

Lewy, Z. and Cappetta, H. 1989. Senonian elasmobranch teeth from Israel. Biostratigraphic and paleoenvironmental implications. Neues Jahrbuch für Geologie und Paläontologie, Monatshefte, 1989 (4), 212-222.

Mourier, T., Bengtson, P., Bonhomme, M., Buge, E., Cappetta, H., Crochet, J.-Y., Feist, M., Hirsch, K.F., Jaillard, E., Laubacher, G., Lefranc, J.P., Moullade, M., Noblet, C., Pons, D., Rey, J., Sigé, B., Tambareau, Y. and Taquet, P. 1988. The Upper Cretaceous - Lower Tertiary marine to continental transition in the Bagua basin, northern Peru. Newsletter on Stratigraphy, 19, 143-177.

Müller, A. 1989. Selachier (Pisces: Neoselachii) aus dem höheren Campanium (Oberkreide) Westfalens (Nordrhein-Westfalen, NW-Deutschland). Geologie und Paläontologie in Westfalen, 14, 1-161.

Nessov, L.A. 1997. Cretaceous nonmarine vertebrates of Northern Eurasia. The University of Sankt-Petersburg, St. Petersburg, 218 pp.

Slaughter, B.H. and Springer, S. 1968. Replacement of rostral teeth in sawfishes and sawsharks. Copeia, 1968, 499-506.

Slaughter, B.H. and Steiner, M. 1968. Notes on rostral teeth of ganopristine sawfishes, with special reference to Texas material. Journal of Paleontology, 42, 233-239.

Smith, R. 1999. Elasmobranches nouveaux de la transition Paléocène-Eocène de Dormaal (Belgique). Bulletin de l'institut royal des sciences naturelles de Belgique, Sciences de la Terre, 69, 173-185.

Smith, A.G., Smith, D.G. and Funnel, B.M. 1994. Atlas of Mesozoic and Cenozoic coastlines. Cambridge University Press, Cambridge. 99 pp. 
Stromer, E. 1925. Ergebnisse der Forschungsreisen Prof. E. Stromers in den Wüsten Ägyptens. II. Wirbeltier-Reste der Baharije-Stufe (unterstes Cenoman). 8. Ein Skelettreste des Pristiden Onchopristis numidus Haug sp. Abhandlungen der bayerischen Akademie der Wissenschaften, mathematisch-naturwissenschaftliche Abteilung, 30, 11-22.

Stromer, E. 1927. Ergebnisse der Forschungsreisen Prof. E. Stromers in den Wüsten Ägyptens. II. Wirbeltier-Reste der Baharije-Stufe (unterstes Cenoman). 9. Die Plagiostomen, mit einem Anhang über käno- und mesozoische Rückenflossenstacheln von Elasmobranchiern. Abhandlungen der bayerischen Akademie der Wissenschaften, mathematischnaturwissenschaftliche Abteilung, 31, 1-64.

Thurmond, J.T. 1971. Cartilaginous fishes of the Trinity Group and related rocks (Lower Cretaceous) of North Central Texas. Southeastern Geologist, 13, 207-227.

Thurmond, J.T. 1974. Lower vertebrate faunas of the Trinity Division in north-central Texas. Geoscience and Man, 8, 103-129.

Underwood, C.J. and Mitchell, S. 1999. Albian and Cenomanian selachian assemblages from North-East England. Special Papers in Palaeontology, 60, 9-56.

Uyeno, T. and Hasegawa, Y. 1986. A new Cretaceous ganopristoid sawfish of the genus Ischyrhiza from Japan. Bulletin of the National Science Museum, 12, 67-72.
Weiler, W. 1935. Ergebnisse der Forschungsreisen Prof. E. Stromers in den Wüsten Ägyptens. II. Wirbeltier-Reste der Baharije-Stufe (unterstes Cenoman). 16. Neue Untersuchungen an den Fischresten. Abhandlungen der bayerischen Akademie der Wissenschaften, mathematisch-naturwissenschaftliche Abteilung, N.F., 32, 1-57.

Welton, B.J. and Farish, R.F. 1993. The collector's guide to Fossil sharks and rays from the Cretaceous of Texas. Before Time, Dallas. 204 pp.

Werner, C. 1989. Die Elasmobranchier-Fauna des Gebel Dist Member der Bahariya Formation (Obercenoman) der Oase Bahariya, Ägypten. Palaeo Ichthyologica, 5, 1112.

Williamson, T.E. and Lucas, S.G. 1993. Freshwater selachians from the early Palaeocene of the San Juan Basin, north-western New Mexico, USA. Tertiary Research, 14, 97-105.

Williamson, T.E., Kirkland, J.I. and Lucas, S.G. 1993. Selachians from the Greenhorn Cyclothem ("Middle" Cretaceous: Cenomanian - Turonian), Black Mesa, Arizona, and the paleogeographic distribution of Late Cretaceous selachians. Journal of Paleontology, 67, 447474.

Woodward, A.S. 1892. Description of the Cretaceous sawfish Sclerorhynchus atavus. Geological Magazine, dec. 3, 9, 529-534.

Manuscrito recibido: 5 de noviembre, 1999 Manuscrito aceptado: 18 de julio, 2000 
Appendix 1. Occurrences of sclerorhynchid sawfishes

\begin{tabular}{|c|c|c|c|c|}
\hline Genus & Species & Stratigraphy & Region & Continent \\
\hline Ankistrorhynchus & Ionzeensis & Santonian & \begin{tabular}{|l|} 
Belgium \\
\end{tabular} & Europe \\
\hline Ankistrorhynchus & major & Maastrichtian & New Jersey & N. America \\
\hline Ankistrorhynchus & washakiensis & Campanian & Wyoming & N. America \\
\hline Baharipristis & bastetiae & Cenomanian & Egypte & N. Africa \\
\hline Borodinopristis & schwimmeri & Campanian & Georgia & N. America \\
\hline Borodinopristis & schwimmeri & Santonian & Mississippi & N. America \\
\hline Borodinopristis & schwimmeri & Campanian & Mississippi & N. America \\
\hline cf. Onchosaurus & sp. & Santonian & New Mexico & N. America \\
\hline Ctenopristis & nougareti & Maastrichtian & \begin{tabular}{|l|} 
Angola \\
\end{tabular} & W. Africa \\
\hline Ctenopristis & nougareti & Maastrichtian & Cabinda & W. Africa \\
\hline \begin{tabular}{|l} 
Ctenopristis \\
\end{tabular} & nougareti & Maastrichtian & Irak & Near East \\
\hline Ctenopristis & sp. & Maastrichtian & Syria & Near East \\
\hline Ctenopristis & nougareti & Maastrichtian & Morocco & N. Africa \\
\hline Ctenopristis & nougareti & Thanet (Redeposition) & Morocco & N. Africa \\
\hline \begin{tabular}{|l|} 
Ctenopristis \\
\end{tabular} & nougareti & Maastrichtian & Zaire & W. Africa \\
\hline \begin{tabular}{|l|} 
Dalpiazia \\
\end{tabular} & stromeri & Maastrichtian & Egypte & N. Africa \\
\hline \begin{tabular}{|l|} 
Dalpiazia \\
\end{tabular} & stromeri & Maastrichtian & Libya & N. Africa \\
\hline Dalpiazia & stromeri & Maastrichtian & Morocco & N. Africa \\
\hline \begin{tabular}{|l|} 
Dalpiazia \\
\end{tabular} & stromeri & Maastrichtian & Niger & W. Africa \\
\hline \begin{tabular}{|l|} 
Dalpiazia \\
\end{tabular} & stromeri & Maastrichtian & Zaire & W. Africa \\
\hline \begin{tabular}{|l|} 
Dalpiazia \\
\end{tabular} & stromeri & Maastrichtian & Syria & Near East \\
\hline Ganopristis & leptodon & Campanian-Maastricht. & Israel & Near East \\
\hline Ganopristis & leptodon & Campanian-Maastricht. & Syria & Near East \\
\hline Ganopristis & leptodon & Maastrichtian & Morocco & N. Africa \\
\hline Ganopristis & leptodon & Maastrichtian & The Netherlands & Europe \\
\hline Ganopristis & leptodon & Maastrichtian & Tunisia & N. Africa \\
\hline Ganopristis & sp. & Campanian & Israel & Near East \\
\hline Ischyrhiza & avonicola & Turonian & Arizona & N. America \\
\hline Ischyrhiza & avonicola & Campanian & Montana & N. America \\
\hline Ischyrhiza & avonicola & Maastrichtian & New Jersey & N. America \\
\hline Ischyrhiza & avonicola & Campanian & New Mexico & N. America \\
\hline Ischyrhiza & avonicola & Turonian & New Mexico & N. America \\
\hline Ischyrhiza & avonicola & Turonian & S. Dakota & N. America \\
\hline Ischyrhiza & avonicola & Turonian-Maastrichtian & Texas & N. America \\
\hline Ischyrhiza & avonicola & Maastrichtian & Wyoming & N. America \\
\hline
\end{tabular}

\begin{tabular}{|c|c|c|c|c|}
\hline Ischyrhiza & basinensis & Campanian & Wyoming & N. America \\
\hline Ischyrhiza & cf. avonicola & Campanian & Wyoming & N. America \\
\hline Ischyrhiza & germaniae & Campanian & NW. Germany & Europe \\
\hline Ischyrhiza & hartenbergeri & Maastrichtian & Bolivia & S. America \\
\hline Ischyrniza & iwakiensis & Coniacian-Santonian & Japan & Pacific \\
\hline Ischyrhiza & mira & Montian (Redeposition) & Texas & N. America \\
\hline Ischyrhiza & mira & Campanian-Maastricht. & Texas & N. America \\
\hline Ischyrhiza & mira & Campanian & Alberta & N. America \\
\hline Ischyrhiza & mira & Campanian & Mississippi & N. America \\
\hline Ischyrhiza & mira & Campanian & Montana & N. America \\
\hline Ischyrhiza & mira & Maastrichtian & N. Carolina & N. America \\
\hline Ischyrhiza & mira & Maastrichtian & New Jersey & N. America \\
\hline Ischyrniza & mira & Santonian & New Mexico & N. America \\
\hline Ischyrhiza & mira & Coniacian & New Mexico & N. America \\
\hline Ischyrhiza & mira & Turonian & New Mexico & N. America \\
\hline Ischyrhiza & mira & Maastrichtian & Texas & N. America \\
\hline Ischyrhiza & mira & Turonian-Senonian & Texas & N. America \\
\hline Ischyrhiza & mira & Turonian-Maastrichtian & $\begin{array}{l}\text { Texas } \\
\end{array}$ & N. America \\
\hline Ischyrhiza & mira & Campanian & W. Georgia & N. America \\
\hline Ischyrhiza & mira & Campanian & Wyoming & N. America \\
\hline Ischyrhiza & monasterica & Maastrichtian & Texas & N. America \\
\hline Ischyrhiza & nigeriensis & Maastrichtian & Niger & W. Africa \\
\hline Ischyrhiza & roessingi & Campanian & Wyoming & N. America \\
\hline Ischyrhiza & schneideri & Cenomanian-Turonian & Arizona & N. America \\
\hline Ischyrhiza & schneideri & Coniacian & New Mexico & N. America \\
\hline Ischyrhiza & schneideri & Turonian-Coniacian & Texas & N. America \\
\hline Ischyrhiza & serra & Turon.-Coniac., Sant.? & Uzbekistan & Eurasia \\
\hline Ischyrhiza & sp. & Campanian & Montana & N. America \\
\hline Ischyrhiza & sp. & Campanian & Montana & N. America \\
\hline Ischyrhiza & sp. & Campanian & Kazakhstan & Eurasia \\
\hline Ischyrhiza & sp. & Paleocene (reworked) & Belgium & Europe \\
\hline Ischyrhiza & viaudi & Santonian & W. France & Europe \\
\hline Isch. or Dalpiazia & sp. & Campanian & Peru & S. America \\
\hline Libanopristis & hiram & Cenomanian & Lebanon & Near East \\
\hline Marckgrafia & libyca & Cenomanian & Egypte & N. Africa \\
\hline
\end{tabular}

\begin{tabular}{|c|c|c|c|c|}
\hline Micropristis & solomonis & Santonian & Belgium & Europe \\
\hline Micropristis & solomonis & Cenomanian & \begin{tabular}{|l|l|} 
\\
\end{tabular} & Near East \\
\hline Micropristis? & sp. & Campanian & NW. Germany & Europe \\
\hline Onchopristis & cf. dunklei & \begin{tabular}{|l|} 
Albian \\
\end{tabular} & \begin{tabular}{|l|} 
Texas \\
\end{tabular} & N. America \\
\hline Onchopristis & cf. numidus & Cenomanian & Texas & N. America \\
\hline Onchopristis & d. praecursor & Aptian/Albian & Texas & N. America \\
\hline Onchopristis & dunklei & Cenomanian & Arizona & N. America \\
\hline Onchopristis & dunklei & \begin{tabular}{|l|} 
Barremian \\
\end{tabular} & E. Spain & Europe \\
\hline Onchopristis & dunklei & Cenomanian & Egypte & N. Africa \\
\hline Onchopristis & dunklei & Cenomanian/Turonian & Greenland & Europe \\
\hline Onchopristis & dunklei & Cenomanian & Minesota & N. America \\
\hline Onchopristis & dunklei & Cenomanian? & N. France & Europe \\
\hline Onchopristis & dunklei & Cenomanian & SW. France & Europe \\
\hline Onchopristis & dunklei & Cenomanian & Texas & N. America \\
\hline Onchopristis & dunklei & Cenomanian & Texas & N. America \\
\hline Onchopristis & dunklei & Cenomanian & Texas & N. America \\
\hline Onchopristis & dunklei & Campanian & Texas & N. America \\
\hline Onchopristis & dunklei & Albian-Cenomanian & Texas & N. America \\
\hline Onchopristis & dunklei & Albian & Texas & N. America \\
\hline Onchopristis & numidus & U. Albian & Algeria & N. Africa \\
\hline Onchopristis & numidus & Cenomanian & Egypte & N. Africa \\
\hline Onchopristis & numidus & Cenomanian & Egypte & N. Africa \\
\hline Onchopristis & numidus & Cenomanian & Egypte & N. Africa \\
\hline Onchopristis & numidus & Cenomanian & Morocco & N. Africa \\
\hline Onchopristis & sp. & Barremian & E. Spain & Europe \\
\hline Onchopristis & sp. & U. Cretaceous & India & Asia \\
\hline Onchopristis & sp. & Santonian-Campanian & Libya & N. Africa \\
\hline Onchopristis & sp. & Aptian & Texas & N. America \\
\hline \begin{tabular}{|l} 
Onchosaurus \\
\end{tabular} & cf. radicalis & Turonian & Ecuador & S. America \\
\hline Onchosaurus & pharao & Senonian & Angola & W. Africa \\
\hline Onchosaurus & pharao & Senonian & Brazil & S. America \\
\hline Onchosaurus & pharao & Santonian & Egypte & N. Africa \\
\hline \begin{tabular}{|l} 
Onchosaurus \\
\end{tabular} & pharao & Turonian & Niger & W. Africa \\
\hline \begin{tabular}{|l|} 
Onchosaurus \\
\end{tabular} & pharao & Campanian & Texas & N. America \\
\hline Onchosaurus & pharao & Senonian & Zaire & W. Africa \\
\hline \begin{tabular}{|l} 
Onchosaurus \\
\end{tabular} & radicalis & Senonian & N. France & Europe \\
\hline Plicatopristis & strougoi & Maastrichtian & Egypte & N. Africa \\
\hline Plicatopristis & strougoi & Maastrichtian & Syria & Near East \\
\hline Pucapristis & branisi & Maastrichtian & Bolivia & S. America \\
\hline Pucapristis & branisi & Maastrichtian & Bolivia & S. America \\
\hline Pucapristis? & standhardtae & Paleocene (Misident.) & New Mexico & N. America \\
\hline Schizorhiza & aff. stromeri & Campanian-Maastricht. & Bolivia & S. America \\
\hline Schizorhiza & cf. stromeri & Maastrichtian & Texas & N. America \\
\hline Schizorhiza & stromeri & Maastrichtian & Angola & W. Africa \\
\hline Schizorhiza & stromeri & Maastrichtian & Bolivia & S. America \\
\hline Schizorhiza & stromeri & Maastrichtian & Chile & S. America \\
\hline \begin{tabular}{|l|} 
Schizorhiza \\
\end{tabular} & stromeri & Maastrichtian & Egypte & N. Africa \\
\hline \begin{tabular}{|l|} 
Schizorhiza \\
\end{tabular} & stromeri & Maastrichtian & Iraq & Near East \\
\hline \begin{tabular}{|l} 
Schizorhiza \\
\end{tabular} & stromeri & Maastrichtian & Jordania & Near East \\
\hline \begin{tabular}{|l} 
Schizorhiza \\
\end{tabular} & stromeri & Maastrichtian & Syria & Near East \\
\hline \begin{tabular}{|l|} 
Schizorhiza \\
\end{tabular} & stromeri & Maastrichtian & Libya & N. Africa \\
\hline Schizorhiza & stromeri & Maastrichtian & Morocco & N. Africa \\
\hline Schizorhiza & stromeri & Maastrichtian & Niger & W. Africa \\
\hline Schizorhiza & stromeri & Maastrichtian & Nigeria & W. Africa \\
\hline Schizorhiza & stromeri & Maastrichtian & Texas & N. America \\
\hline Schizorhiza & stromeri & Maastrichtian & Tunisia & N. Africa \\
\hline Schizorhiza & stromeri & Maastrichtian & Zaire & W. Africa \\
\hline Sclerorhynchus & atavus & Santonian & \begin{tabular}{|l} 
Lebanon \\
\end{tabular} & Near East \\
\hline Sclerorhynchus & batavicus & Maastrichtian & \begin{tabular}{|l} 
Netherlands \\
\end{tabular} & Europe \\
\hline Sclerorhynchus & cf. pettersi & Paleocene (reworked) & \begin{tabular}{|l|l|} 
Belgium \\
\end{tabular} & Europe \\
\hline Sclerorhynchus & fanninensis & Campanian & Texas & N. America \\
\hline Sclerorhynchus & \begin{tabular}{|l|} 
n. sp. \\
\end{tabular} & Cenomanian & Mississippi & N. America \\
\hline Sclerorhynchus & n. sp. & Campanian & \begin{tabular}{|l} 
Peru \\
\end{tabular} & S. America \\
\hline Sclerorhynchus & palaeocenicus & Paleocene (misident.) & Morocco & N. Africa \\
\hline Sclerorhynchus & pettersi & Maastrichtian & Texas & N. America \\
\hline Sclerorhynchus & priscus & Turonian-Coniacian & Texas & N. America \\
\hline Sclerorhynchus & sp. & Campanian & Israel & Near East \\
\hline Sclerorhynchus & sp. & Campanian & Mississippi & N. America \\
\hline Sclerorhynchus & sp. & Senonian & Morocco & N. Africa \\
\hline Sclerorhynchus & sp. & Campanian & Texas & N. America \\
\hline Sclerorhynchus & sp. & \begin{tabular}{|l|} 
Turonian-Coniacian \\
\end{tabular} & Texas & N. America \\
\hline \begin{tabular}{|l} 
Sclerorhynchus \\
\end{tabular} & sp. & \begin{tabular}{|l|} 
U. Cretaceous \\
\end{tabular} & & Arabia \\
\hline Sclerorhynchus? & sp. & Campanian? & \begin{tabular}{|l|l} 
Japan \\
\end{tabular} & Pcific \\
\hline Sclerorhynchus? & sp. & Campanian-Maastricht. & New Zealand & Pacific \\
\hline Sclerohynchidae & indet. & Campanian-Maastricht. & Peru & S. America \\
\hline Sclerohynchidae? & indet. & U. Albian-L. Cenom. & England & Europe \\
\hline Sclerorhynchidae? & indet. & Campanian & NW. Germany & Europe \\
\hline
\end{tabular}

